\title{
MONISMO DA DURAÇÃO E ONTOLOGIZAÇÃO DO PASSADO: SOBRE A LEITURA DELEUZEANA DE BERGSON
}

\author{
Fernando Monegalha ${ }^{1}$
}

\begin{abstract}
Resumo: Trata-se de avaliar a justiça da leitura deleuzeana de Bergson, partindo de duas problemáticas principais: o monismo da duração, que Deleuze enxerga e defende em Bergson, e a ontologização do passado, a qual ele promove em sua apreciação da filosofia bergsoniana. Como procuraremos mostrar, se o primeiro ponto (o monismo da duração) parece particularmente equivocado, o segundo ponto (a ontologizaçáo do passado) parece encontrar guarida em alguns trechos da obra de Bergson.
\end{abstract}

Palavras-Chave: duração - monismo - virtual - atual - ontologia

\section{INTRODUÇÃo}

Num célebre trecho da Carta a um critico severo, Deleuze explica que o único modo de conseguir escapar da ênfase sufocante na historiografia que assolava a filosofia francesa do seu tempo "[...] foi concebendo a história da Filosofia como uma espécie de enrabada, ou, o que dá no mesmo, de imaculada concepção." (DELEUZE, 2007, p. 14). Deleuze (2007, p. 14) se imaginava entâo "[...] chegando pelas costas de um autor e lhe fazendo um filho, que seria seu, e no entanto seria monstruoso", o que é um outro modo de dizer que, para além da fidedignidade ao pensamento por ele estudado, ele também buscava fazer da exegese textual um exercício de criação, no qual a força disruptiva original dos autores por ele estudados fosse de algum modo resgatada, o que implicava, por sua vez, a necessidade de certos deslocamentos conceituais capazes de restabelecer o vigor original de um pensamento (além de fazê-los exprimir, diga-se de passagem, a própria filosofia deleuzeana em gestação):

Que fosse seu era muito importante, porque o autor precisava efetivamente ter dito tudo aquilo que eu lhe fazia dizer. Mas que o filho fosse monstruoso também representava uma necessidade, porque era preciso passar por toda espécie de descentramentos, deslizes, quebras, emissóes secretas que me deram muito prazer. (DELEUZE, 2007, p. 14).

\footnotetext{
${ }^{1}$ Professor Adjunto da UFAL (Universidade Federal de Alagoas). Doutorou-se em Filosofia pela UFSCar, com a tese $O$ atual e o virtual em Bergson e Deleuze. Atualmente, dedica-se a estudar as temáticas da temporalidade e do acontecimento na filosofia francesa contemporânea. E-mail: fmonegalha@uol.com.br
}

http://dx.doi.org/10.1590/S0101-317320170002000011 
Como esclarece Deleuze (2007, p. 14), “[...] meu livro sobre Bergson me parece exemplar nesse gênero", referindo-se aqui a Bergsonismo, a principal obra por ele consagrada à exegese do filósofo. Essa é uma indicação preciosa, pois não podemos deixar de nos perguntar, no contexto deste artigo, qual seria essa monstruosidade criada por Deleuze em sua leitura de Bergson. Hoje em dia, os intérpretes de Bergson são quase unânimes em apontar que ela residiu justamente no fato de Deleuze ter transformado a pluralidade de duraçóes bergsonianas numa única substância-duraçáo, promovendo, assim, um entrecruzamento monstruoso entre Bergson e Spinoza. ${ }^{2}$ Segundo esses intérpretes, nesse monstro criado por Deleuze, a consciência individual - tão fundamental para Bergson - teria sido completamente absorvida numa única duração universal, da qual ela não seria mais do que um "modo", para usar a nomenclatura spinozana. A "substancialidade" de nossas duraçôes pessoais seria, desse modo, preterida por um monismo da duração, sem lugar para a pessoa e o indivíduo, táo caros a Bergson.

Aqueles leitores que possuem alguma familiaridade com o pensamento filosófico já sabem: estamos diante de uma reedição da antiquíssima discussão entre monismo e pluralismo substanciais, com os intérpretes de Bergson defendendo o pluralismo substancial deste, enquanto Deleuze, por sua vez, defenderia, na visão deles, um monismo substancial. ${ }^{3}$ Para alguns dos intérpretes de Bergson, essa afirmação de um monismo da duração seria uma consequência direta da ontologizaçáo do pensamento bergsoniano por Deleuze, a qual o teria levado a esquecer o pano de fundo psicológico desse pensamento, calcado fundamentalmente na intuição da duração, na intuição direta do próprio tempo. ${ }^{4}$

\footnotetext{
${ }^{2}$ Podemos citar, a esse respeito, entre outros, o livro de Pierre Montebello, Deleuze la passion de la pensée (2008, p. 220 et seq., numa seção sugestivamente chamada "Un Bergson spinoziste"), além do artigo de Camille Riquier, intitulado Bergson (d')après Deleuze.

${ }^{3}$ A esse respeito, nós lembramos que é o próprio Bergson quem utiliza o termo "substância", em alguns momentos de sua obra, para se referir à duração, conferindo a esse termo, porém, uma acepção metafisicamente menos carregada do que aquela que lhe foi outorgada pela tradiçáo: substância, ousia, para o filósofo francês, designa não um substrato ao qual inerem os diversos acidentes, mas simplesmente a persistência característica de qualquer entidade que dure, como se pode ver nesta nota esclarecedora de Introdução à Metafísica: "Mais uma vez, náo afastamos com isso de modo algum a substância. Afirmamos, pelo contrário, a persistência das existências. E acreditamos ter-lhe facilitado a representação. Como se pôde comparar essa doutrina à de Heráclito?” (BERGSON, 2006b, p. 218). Portanto, ao falar de um monismo e de um pluralismo substanciais, referimo-nos a essa acepção mais fraca de "substância" que o filósofo tem em vista; nesse sentido, a discussão versa basicamente sobre a existência ou não de diversos fluxos duracionais independentes.
}

${ }^{4}$ Devemos a Camille Riquier uma exposição sintética bastante apurada dessa posição: "Por mais paradoxal que seja, o tempo de Deleuze-Bergson [isto é, de Bergson lido e apropriado por Deleuze] não era temporal. Entretanto, ao se instalar na imediaticidade daquilo que se dá à consciência, Bergson 
Náo temos como entrar aqui na questão da justiça de tais críticas; somente gostaríamos de pontuar que, ao reclamar da suposta não fidedignidade do pensamento deleuzeano a Bergson, alguns desses intérpretes parecem reclamar um ideal de verdade historiográfico que é completamente alienígena àquilo que propóe Deleuze. Que Deleuze tenha deliberadamente obliterado o pensamento bergsoniano é algo que ele diz com todas as letras, no trecho supracitado da Carta..., e ninguém poderia duvidar seriamente disso. Mas a questão que importa é, na verdade, inteiramente outra, a saber: será que sem esse travestimento do pensamento bergsoniano por Deleuze, sem essa metamorfose de uma filosofia espiritualista e personalista numa espécie de anti-humanismo radical, o bergsonismo teria mantido sua chama minimamente acesa desde os idos dos anos 50 ? $^{5}$ Náo terá sido essa falsificação do pensamento bergsoniano a condição sine qua non para ele manter-se minimamente vivo, num período em que quase todos abriam a boca para proclamar a "morte do homem", tal como ocorreu nos anos 70 e 80 ? Nesse sentido, quando reclamamos uma correção exegética dos excessos deleuzeanos, não o fazemos justamente porque a sua genial falsificação nos deu o ensejo mesmo de compreendermos melhor Bergson? Em última instância, não seria melhor que mencionarmos os erros de Deleuze, em sua leitura de Bergson, tratarmos das grandes criaçóes deleuzeanas, lembrando que estamos diante de um pensador para quem a criação sempre assumiu um papel epistemológico muito maior do que a verdade?

Acreditamos numa resposta afirmativa a esta última questão e, por isso, abordaremos sua obra maior sobre Bergson a partir do prisma da criação. Não temos, evidentemente, condiçóes de fazer uma análise exaustiva de Bergsonismo em poucas páginas, nem é o que pretendemos aqui. O que buscamos é somente ver nessa obra dois grandes deslocamentos promovidos por Deleuze na leitura tradicional de Bergson: primeiro, sua compreensão ontológica - e não psicológica - do passado, passado este que Deleuze declarará ser o próprio

adota um ponto de partida resolutamente cartesiano, aquele de um eu imerso na extensão e no tempo concretos. Ele se encontra bem preso numa duraçấo indefectível, que ele nâo pode amputar de sua pessoa sem cessar de ser - tempo que náo é o número que se teria podido eliminar dele e ao qual a medida científica o tinha reduzido. É a esta experiência inicial que a obra inteira continua a voltar como sua única pedra de toque, mas é dela que Deleuze buscava de uma só vez sair para saltar, num pulo, numa ontologia do virtual: como um rio que transborda o seu leito, a duração pura se tornaria um outro nome para a Diferença, o Virtual, o Ser, O Um, o Todo." (RIQUIER, 2008, p. 360, tradução nossa). Cabe ressaltar que essa leitura de Riquier parece bastante influenciada pelas críticas de Alain Badiou a Deleuze.

${ }^{5}$ Ao menos na França, já que sabemos que no Brasil o trabalho de Bento Prado Júnior possibilitou o desenvolvimento de uma linha independente de exegese do pensamento bergsoniano. 
"ser em si"; em segundo lugar, veremos a estratégia argumentativa sui generis que o levou a declarar que, para Bergson, não haveria, no fim das contas, uma pluralidade de duraçóes, mas uma única duração. Como defenderemos, o primeiro deslocamento é de fundamental importância para a compreensão dos objetivos últimos da filosofia bergsoniana, pois Bergson buscou, de fato, a nosso ver, erigir uma ontologia onde a tese da existência (ou insistência) do passado tem um papel de destaque - como veremos, existem bons elementos para essa leitura ontológica do passado em Matéria e memória. Já o segundo deslocamento traz consigo, sem dúvida, uma tese de difícil acomodação nos quadros do próprio bergsonismo, uma vez que Bergson sempre defendeu a existência de uma pluralidade de durações. Porém, isso não impede que esse deslocamento seja considerado, fora dos quadros estritos da exegese textual, uma importante criação deleuzeana a partir de Bergson. Em suma, o que tentaremos mostrar é que a ideia de uma ontologia do passado virtual é necessária para compreendermos Bergson; já a questão do monismo da duração, embora equivocada do ponto de vista da análise textual, é igualmente necessária para entendermos o pensamento de Deleuze.

Para tanto, iremos abordar primeiramente a questão da ontologização do passado que Deleuze promove em sua leitura da obra de Bergson. Antes, contudo, de passarmos à leitura deleuzeana de Bergson, partiremos de uma leitura da obra do próprio Bergson, pois será com base nela que a justiça da argumentação deleuzeana a esse respeito se tornará mais evidente. $\mathrm{O}$ nosso ponto de partida a esse respeito serão dois trechos da obra de Bergson, em que ele se debruça sobre o sentido do termo "existência". Como veremos, o problema que incomoda particularmente Bergson, nessas passagens, é a precedência que se dá habitualmente à existência atual sobre a existência (ou insistência) do passado inconsciente. Com efeito, para Bergson, temos a tendência a pensar o real pelo prisma da existência presente, declarando como simplesmente não-existente tudo aquilo que não tenha o modo de ser da atualidade. É exatamente esse pressuposto habitual de nosso pensamento que Bergson tratará de questionar.

\section{A OnTOlogizaÇÃo do PASSADo: as TESES ACERCA DA EXISTÊNCIA EM BERGSON}

Falamos ordinariamente de existir, de existência, mas o que esses termos significam e qual o sentido deles? Essa é uma questão que assola a Filosofia desde seus primórdios (lembremos, a esse respeito, do Parmênides de Platão ou do 
livro $\Gamma$ da Metafísica de Aristóteles), e Bergson se defronta com ela pelo menos em dois momentos de sua obra: no terceiro capítulo de Matéria e memória e no começo de $A$ evolução criadora. Ele fornece, então, duas respostas bastante diferentes a essa questão, o que se mostra plenamente justificado, já que, num primeiro momento, ele está preocupado em explicar o que nós ordinariamente entendemos por "existente" (Matéria e memória) e, num segundo momento, em explicar o que ele, Bergson, entende por "existência” (A evolução criadora). Sabendo disso, leiamos a primeira dessas respostas:

Tocamos aqui o problema capital da existência, problema que podemos apenas roçar, sob pena de sermos conduzidos, de questão em questão, ao próprio núcleo da metafísica. Digamos simplesmente que, no que concerne às coisas da experiência - a existência parece implicar duas condiçóes reunidas: 1) a apresentação à consciência; 2) a conexão lógica ou causal daquilo que é assim apresentado com o que precede ou que se segue. (BERGSON, 1999, p. 171-172).

Com efeito, declaramos que estamos diante de algo "existente", quando esse algo se apresenta para nossa consciência e, além disso, exibe certo encadeamento lógico ou causal: é a reuniáo desses dois critérios que nos permite distinguir, na maioria das vezes, uma percepção de uma alucinação. Assim, declaramos que o livro à nossa frente "existe", porque primeiramente ele se apresenta à nossa consciência, mas também porque há certo encadeamento entre nossas percepçóes, certa estabilidade entre elas, a qual nos possibilita dizer que não se trata, nesse caso, apenas de um sonho ou uma alucinação.

Contudo, ao mesmo tempo que declaramos que um objeto percebido por nós "existe", também declaramos que "existem" outros tipos de entidade, além dos objetos percebidos por nós: números, juízos, objetos físicos não percebidos atualmente, fantasias, ilusôes etc. Para Bergson, isso mostra claramente que um dos dois critérios acima propostos pode prevalecer sobre o outro, o que evidencia, por sua vez, que existem graus possíveis entre eles. Por exemplo: nós também declaramos que o universo material ao nosso redor "existe", embora tenhamos somente uma pífia apresentação deste à consciência (por meio da percepção pura). O que garante, nesse caso, a afirmação da existência do universo não é, portanto, a sua apresentação à consciência, mas sua conexão causal, isto é, a estabilidade que encontramos nos fenômenos materiais, nos objetos exteriores a nós. Por outro lado, no caso de nossos estados internos, como sonhos e fantasias, temos a situação invertida: constatamos então uma 
variabilidade e instabilidade enorme dos fenômenos; ao mesmo tempo, a apresentação destes à consciência é perfeita, o que nos assegura que eles também "existem" (no sentido de terem existência meramente na mente de um sujeito). Bem pensado, se supomos os dois critérios propostos por Bergson, com seus respectivos graus, poderemos simplesmente ordenar a quase totalidade dos fenômenos que declaramos "existentes", como no gráfico a seguir:

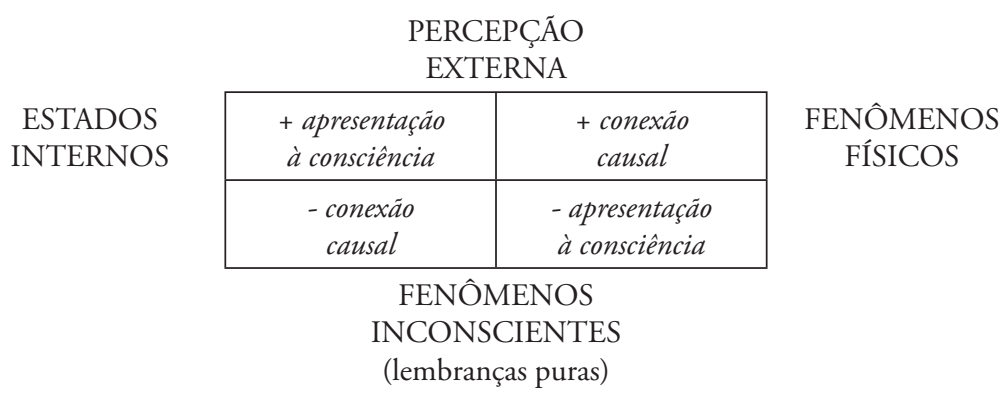

Figura 1 - Tabela da existência

Esse gráfico tem também a vantagem de explicar por que temos tanta dificuldade em conceber a existência de fenômenos inconscientes, tais como nossas lembranças puras, pois, neste último caso, parece faltar a elas tanto a apresentação à consciência quanto a conexáo lógico/causal, devido ao fato de elas se encontrarem fundidas em nossa consciência, num estado confuso. Decorre daí, para Bergson, a tendência de grande parte da filosofia e da ciência de sua época em declarar que os fenômenos inconscientes simplesmente não existem, já que eles não se encaixariam nas categorias correntes dos fenômenos mentais ou físicos, o que equivale a dizer que eles simplesmente não teriam lugar no ser. A consequência básica desse tipo de raciocínio é que a existência seria então reduzida ao atual: poderíamos declarar que o universo e os corpos "existem", que os objetos por nós percebidos "existem", que até mesmo estados internos como nossos devaneios, delírios e alucinações "existem" (num sentido fraco do termo). Em comum, todos esses setores do real têm a propriedade de existir no presente, e táo somente no presente. Se assim fosse, o passado, o virtual, o inconsciente não poderiam então "existir" de forma alguma.

Mas essa situação não nos leva a um patente absurdo? Pois não há, para Bergson, nenhum estado de consciência presente que não esteja permeado de passado: mesmo a nossa sensação mais simples já incorpora em si um 
monumental número de repetiçôes passadas da matéria. E, se assim é com uma simples sensação, o que dizer então de nossa personalidade, dessa monumental totalização retencional de tudo aquilo que sentimos, queremos e pensamos? Não devemos dizer que, comparada a uma efêmera sensação, nossa personalidade e nosso Eu têm uma existência muito mais plena, na medida em que ele carrega consigo um passado muito mais longínquo do que aquele que encontramos em qualquer estado corporal? Como então podemos descartar o passado, o inconsciente, afirmando que eles simplesmente náo existem para nós? Náo seria muito mais correto asseverar que, em certo sentido, o passado existe para nós muito mais do que o presente?

Você define arbitrariamente o presente como o que é, quando o presente é simplesmente o que se faz. Nada é menos do que o momento presente, se você entender por isso esse limite indivisível que separa o passado do futuro. Quando pensamos esse presente como devendo ser, ele ainda náo é; e, quando o pensamos como existindo, ele já passou. Se, ao contrário, você considerar o presente concreto e realmente vivido pela consciência, pode-se afirmar que esse presente consiste em grande parte no passado imediato. [...] Nós só percebemos, praticamente, o passado, o presente puro sendo o inapreensível avanço do passado a roer o futuro. (BERGSON, 1999, p. 175-176).

Eis aqui o germe da inversão ontológica proposta por Matéria e memória, a qual Deleuze levará, por sua vez, ao limite: quando pensamos a questão da existência sub specie durationis, descobrimos que o passado existe para nós muito mais do que o presente. Com efeito, quando nos debruçamos sobre essa multiplicidade de sensaçóes, afecçóes, emoçóes etc. que povoam nossa consciência, descobrimos em todas elas a persistência do passado, persistência que se torna mais evidente ainda quando refletimos sobre nossa própria pessoa, sobre nosso próprio Eu. E o mesmo que acontece com nossa consciência acontece igualmente, para Bergson, com o universo material ao nosso redor; se pudéssemos mergulhar na própria vida caótica da matéria, coincidindo com seu próprio ritmo maníaco, também aí veríamos uma contraçáo ínfima se operando e o trabalho do passado a se processar. Em todos esses casos, verificamos que nunca apreendemos o presente puro e simples, mas apenas um presente carregado de passado, um presente que expressa o passado. Nesse sentido, assim como podemos afirmar que o passado insiste no presente, também podemos afirmar que o presente existe no passado - essa será, pelo menos, a conclusão de um Deleuze em Bergsonismo. 
Essa inversão ontológica proposta por Bergson implica uma grande mudança em nossos hábitos usuais de pensamento, pois, para nós, aquilo que há de usualmente mais estável é, sem dúvida, aquilo que se apresenta a nós no presente, e no presente apenas, a saber, a matéria: o que há de mais permanente em nossa vida cotidiana do que uma pedra, do que uma pirâmide? Ora, de um ponto de vista bergsoniano, tudo isso talvez seja proveniente das imobilizaçóes operadas no devir material por nossa sensibilidade e nosso intelecto, imobilizaçóes possibilitadas, sem dúvida, pela própria tendência interna das coisas materiais à repetição. De acordo com Bergson, se a matéria está num presente que se reinicia sem cessar, então podemos dizer que, comparativamente ao espírito, nada existe menos do que a matéria, nada existe menos do que nosso corpo: "[...] considerado desse novo ponto de vista, com efeito, nosso corpo não é nada mais que a parte invariavelmente renascente de nossa representação, a parte sempre presente, ou melhor, aquela que acaba a todo momento de passar" (BERGSON, 1999, p. 177). Salientemos que é exatamente a fim de representar essa desproporção existencial entre a enorme duração de nosso passado individual e a efêmera duração do nosso corpo e da matéria que o cerca que Bergson propóe o seu famoso gráfico do cone invertido:

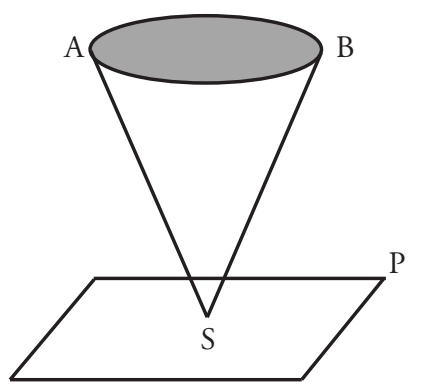

Figura 2 - O "cone invertido"

É difícil não concordar com Deleuze que esse gráfico tem uma significação essencialmente ontológica: o que Bergson parece querer nos indicar aqui é que o nosso passado inconsciente (representado pela base $\mathrm{AB}$ ) constitui uma existência excessiva, quando contraposta à nossa tênue existên- 
cia material e corporal (indicada pela ponta S). Nesse sentido, ele revela perfeitamente a inversão ontológica proposta por Bergson, anteriormente, concedendo uma primazia ontológica ao passado sobre o presente. Essa impressão é reforçada quando lembramos que, na descrição de Bergson, ele afirma que a base do cone permanece "imóvel", enquanto a ponta dele "avança sem cessar" ", o que é outro modo de dizer que, no esquema ontológico proposto por Bergson, é o passado que permanece, enquanto o presente simplesmente passa, não para de passar. A própria possibilidade de falarmos de uma sucessáo de momentos presentes repousa no fato de estes momentos presentes permanecerem retidos em nosso passado. Outra forma de dizê-lo seria afirmar que, contraposta à ínfima duração de nosso corpo e da matéria ao nosso redor, a nossa consciência pessoal constitui um monumental campo temporal, cujo horizonte de passado (mas também de futuro) extrapola enormemente o ínfimo horizonte desse campo temporal menor que é nosso corpo. É nesse ponto que repousa basicamente o excesso de nossa vida espiritual sobre nossa vida corporal.

No entanto, o que esse gráfico do cone nos mostra ainda é que, para Bergson, jamais podemos separar totalmente a vida espiritual da vida corporal, pois não podemos pensar uma sem pensar necessariamente a outra; nesse sentido, jamais poderemos reduzir a nossa vida espiritual à nossa existência corporal, mas também jamais conseguiremos pensar o espírito sem igualmente pensar a matéria. O grande mérito de Bergson foi exatamente ter conseguido instalar-se nesse entre-dois, nessa diferença aberta entre os abismos temporais da matéria e a enorme duração de nossa consciência pessoal. Muito menos do que defender um dualismo substancial entre a matéria e o espírito, o que Bergson buscou, num linguajar mais deleuzeano, foi pensar a diferença interna entre a matéria e o espírito, entre o atual e o virtual, diferença interna essa indefinidamente variável, visto que há toda uma multiplicidade de níveis possíveis de nossa consciência. ${ }^{7}$

\footnotetext{
${ }^{6}$ Eis o texto explicativo do próprio Bergson: "Se eu representar com um cone SAB a totalidade das lembranças acumuladas em minha memória, a base $\mathrm{AB}$, assentada no passado, permanece imóvel, enquanto o vértice $S$, que figura a todo momento meu presente, avança sem cessar, e sem cessar também toca o plano móvel $\mathrm{P}$ de minha representação atual do universo. Em $S$ concentra-se a imagem do corpo; e, fazendo parte do plano P, essa imagem limita-se a receber e a devolver as açóes emanadas de todas as imagens de que se compóe o plano.” (BERGSON, 1999, p. 177-178).

7 De um modo bastante simplificado, podemos afirmar que a ontologia proposta por Bergson nos leva a ampliar o próprio escopo do que entendemos por "existência", pois ela busca abarcar tanto a "existência" material quanto a "insistência" espiritual; ela deve ser, portanto, uma ontologia do atual e
} 
E, com isso, chegamos à segunda definição de "existência", proposta por Bergson, no início de $A$ evolução criadora. ${ }^{8}$ Contraposta à complexidade da análise de Matéria e memória, ela possui, sem dúvida, uma simplicidade espantosa: "[...] para um ser consciente, existir consiste em mudar, mudar, em amadurecer, amadurecer, em criar-se indefinidamente a si mesmo." (BERGSON, 2005, p. 8). Mudar, amadurecer, criar-se: se repararmos bem, veremos que essas são três propriedades essenciais da duração, como o próprio Bergson anota mais adiante: "[...] quanto mais aprofundarmos a natureza do tempo, melhor compreenderemos que duração significa invenção, criação de formas, elaboração contínua do absolutamente novo.” (BERGSON, 2005, p. 12). Ora, como o próprio Bergson nos lembra, em seu texto, a duração não é, para ele, somente uma marca de nossos processos conscientes, mas uma propriedade geral de todas as coisas materiais. Como sabemos, o nosso corpo dura, o próprio universo dura (BERGSON, 2005, p. 12). Logo, podemos assinalar não somente num sentido estrito, mas num sentido muito amplo, que "existir" consiste, para Bergson, simplesmente em durar, na medida em que todos os nossos processos conscientes e corporais duram, assim como duram todos os seres vivos, assim como dura o próprio universo material no qual eles estão instalados. Ao afirmar que "existir = durar", Bergson não está propondo uma mera relação de sinonímia, como ocorre quando, por exemplo, perguntamos a alguém o que significa "ser", e esse alguém nos responde "ser = existir". Neste último caso, não há uma definição efetiva, porque nenhuma informação é de fato fornecida por nosso interlocutor. Ora, ao afirmar que existir consiste, em última instância, em durar, Bergson assevera que tudo o que existe, existe porque retém seu passado no presente, porque contrai seus estados anteriores no atual. Temos aí uma informação efetivamente nova sendo repassada; trata-se, efetivamente, de uma definição.

Existir significa durar, ser significa durar: eis dois enunciados que poderiam sintetizar muito bem boa parte do percurso de pensamento de Bergson. Entretanto, se assim é, podemos dizer que a existência deriva, no fim das contas, da memória: é a memória que faz com que qualquer coisa exista! A me-

do virtual, uma ontologia integral, ao contrário de outras ontologias, as quais acabam por reduzir o real a estados de coisas atuais, sejam estes entidades materiais, sejam representaçóes mentais. Essa ontologia integral proposta por Bergson pode ser considerada uma ontologia bastante econômica, porquanto o que o filósofo nos propóe é que o real é simplesmente composto por diferentes graus de duração, por diferentes planos de consciência, e nada mais.

${ }^{8}$ Qualquer análise da existência em Bergson não pode estar completa, se não passar pelo capítulo IV de A evolução criadora. Como não é esse nosso intento aqui, podemos prescindir de analisar essa parte de sua obra, a qual tem sido considerada, com justiça e por muitos, como central para a filosofia bergsoniana. 
mória, por conseguinte, não tem um papel apenas psicológico para Bergson, mas ontológico: ela é o princípio que rege a existência em geral. Será isto que Deleuze tão bem saberá explorar em sua leitura de Bergson.

\section{A ontologizaçáo do passado: a leitura deleuzeana de Bergson}

Após esse extenso, mas necessário, desvio, chegamos finalmente ao primeiro deslocamento de peso que Deleuze promoveu na filosofia bergsoniana. Que Bergson tenha afirmado o estatuto ontológico do passado, da memória, do inconsciente, é inegável. Porém, se assim é, qual foi o deslocamento operado por Deleuze a esse respeito? Ele consistiu basicamente em levar ao paroxismo aquilo que somente encontrávamos em germe em Bergson, sustentando claramente, em Bergsonismo, que o que existe, de fato, não é o presente, mas o passado:

Se temos tanta dificuldade em pensar uma sobrevivência em si do passado, é porque acreditamos que o passado já não é, que ele deixou de ser. Confundimos então o Ser com o ser-presente. Todavia, o presente não é; ele seria sobretudo puro devir, sempre fora de si. Ele não é, mas age. Seu elemento próprio não é o ser, mas o ativo ou o útil. Do passado, ao contrário, é preciso dizer que ele deixou de agir ou de ser útil. Mas ele não deixou de ser. Inútil e inativo, impassível, ele É, no sentido pleno da palavra: ele se confunde com o ser em si. Não se trata de dizer que ele "era", pois ele é o em-si do ser e a forma sob a qual o ser se conserva em si (por oposiçáo ao presente que é a forma sob a qual o ser se consome e se póe fora de si). No limite, as terminaçóes ordinárias se intercambiam: é do presente que é preciso dizer, a cada instante, que ele "era" e, do passado, é preciso dizer que ele "é", que ele é eternamente, o tempo todo. [...] Devemos compreender desde já que Bergson não emprega a palavra "inconsciente" para designar uma realidade psicológica fora da consciência, mas para designar uma realidade não psicológica - o ser tal como ele é em si. Rigorosamente falando, o psicológico é o presente. Só o presente é "psicológico"; mas o passado é a ontologia pura, a lembrança pura, que tem significação tão somente ontológica. (DELEUZE, 2004, p. 42-43).

Compreendamos: Deleuze está aí promovendo, assim como Bergson fez antes dele, uma inversão completa de nossos esquemas ontológicos convencionais; ele está afirmando que o Ser (com maiúscula) não é a totalidade do que é presente, mas, isto sim, a totalidade do passado. O Ser é o passado, $\mathrm{o}$ inconsciente, o virtual, e não o presente, a consciência, o atual. $\mathrm{O}$ passado 
é o "ser em si", a "ontologia pura". O que tudo isso significa? Basicamente, que, quando pensamos o real sub specie durationis, descobrimos que aquilo que tem permanência e estabilidade não é o presente, mas o passado; é ele que permanece, enquanto o presente não para de passar. Sem essa estabilidade do passado, teríamos somente um presente material que nasce e morre quase no momento mesmo de seu nascimento, e nada além disso. Nesse sentido, ao afirmar que o inconsciente não tem existência psicológica, Deleuze não está simplesmente desqualificando o trabalho da psicanálise, mas, antes, declarando que toda investigação do inconsciente é, antes de mais nada, uma investigação ontológica, uma exploração do próprio Ser em si. Todavia, esse Ser, na medida em que é a própria totalidade do passado, totalidade essencialmente virtual, também é o Ser que não se mostra, que não se revela. De certo modo, podemos assegurar que, para o Deleuze de Bergsonismo, o passado é aquilo que deve permanecer oculto, para que tudo o mais possa aparecer, pois ele é a condição de passagem de todos os presentes.

Na medida em que o inconsciente se torna o próprio Ser em si, o processo de rememoração do passado adquire uma dramaticidade inesperada. Para Deleuze, naquele momento em que, para Bergson, nos colocamos na região do passado puro, das lembranças puras, estamos simplesmente efetuando um verdadeiro salto no Ser:

É certo que Bergson fala em ato psicológico [no caso da rememoração], mas, se esse ato é sui generis, é porque ele consiste em dar um verdadeiro salto. [...] Colocamo-nos incialmente, diz Bergson, no passado em geral: o que ele assim descreve é o salto na ontologia. Saltamos realmente no ser, no ser em si, no ser em si do passado. Trata-se de sair da psicologia: trata-se de uma Memória imemorial ou ontológica. E somente em seguida, uma vez dado o salto, que a lembrança vai ganhar pouco a pouco uma existência psicológica: "de virtual, ela passa ao estado atual". Fomos buscá-la ali onde ela está, no Ser impassível, e demos-lhe pouco a pouco uma encarnação, uma "psicologizaçâo". (DELEUZE, 2004, p. 43-44).

A memória espontânea não tem, definitivamente, de acordo com Deleuze, nenhum sentido psicológico, mas tão só ontológico: ela é o meio pelo qual o próprio Ser conserva-se a si mesmo e, nesse sentido, o próprio em-si do Ser. Nessa perspectiva, a rememoração, a atualização do passado ocupa um papel secundário - ela é o meio pelo qual o Ser se projeta para fora de si, para além de si mesmo. O próprio corpo e a matéria, antes de serem o fundamento ontológico da realidade, são apenas a superfície do real, um corte instantâneo 
da duração universal, seu afundamento numa duração cada vez mais ínfima. De fato, eles nada seriam sem a duração universal que os anima, sem essa persistência ontológica do próprio passado, a qual permanece, entretanto, oculta para nós. ${ }^{9}$ Toda essa reviravolta conceitual proposta por Deleuze pressupóe evidentemente que repensemos o que habitualmente concebemos por "passado". Temos, por exemplo, a tendência a achar que o passado apenas pode se constituir após ter sido presente - disso decorre a distinção de um Hume acerca de nossas impressóes "fortes" e nossas ideias "fracas". Ora, se assim fosse, o passado estaria sempre a reboque do presente, seria somente uma sombra dele, um ser derivado que nunca poderia desempenhar esse papel ontológico central proposto por Deleuze. Para ele, se o passado pode se confundir com o próprio ser em si, não é porque ele derive do presente, mas, antes, porque ele coexiste com o presente:

Temos, em demasia, o hábito de pensar em termos de "presente". Acreditamos que um presente só passa quando outro presente o substitui. Reflitamos, porém: como adviria um novo presente, se o antigo presente nấo passasse ao mesmo tempo em que é presente? Como um presente qualquer passaria, se ele não fosse passado ao mesmo tempo que presente? $\mathrm{O}$ passado jamais se constituiria, se ele já náo tivesse se constituído inicialmente, ao mesmo tempo em que foi presente. Há aí como que uma posição fundamental do tempo, e também o mais profundo paradoxo da memória: o passado é "contemporâneo" do presente que ele foi. [...] O passado jamais se constituiria se ele não coexistisse com o presente do qual ele é passado. $\mathrm{O}$ passado e o presente náo designam dois momentos sucessivos, mas dois elementos que coexistem: um, que é o presente e que não para de passar; o outro, que é o passado e que não para de ser, mas pelo qual todos os presentes passam. (DELEUZE, 2004, p. 45).

Entendamos: na visão de Deleuze, o presente passa, contudo, somente passa porque é retido no ser em si do passado. Se não houvesse essa conservação, o presente nunca passaria, mas simplesmente nasceria e instantaneamente

\footnotetext{
${ }^{9}$ Conforme Deleuze, esse salto no passado que efetuamos no início do processo rememorativo é também um salto no sentido, visto que é por meio dele que nos instalamos naquela região das lembranças puras, responsável por dotar o fato bruto da matéria e da sensibilidade de um sentido espiritual intrínseco: "Com efeito, Bergson analisa a linguagem do mesmo modo como analisou a memória. A maneira pela qual compreendemos o que nos é dito é idêntica àquela pela qual buscamos uma lembrança. Longe de recompor o sentido a partir de sons ouvidos e de imagens associadas, instalamo-nos de súbito no elemento do sentido e, depois, em certa regiâo desse elemento. Verdadeiro salto no Ser. É somente em seguida que o sentido se atualiza em sons fisiologicamente percebidos e nas imagens psicologicamente associadas a esses sons. Há, nesse caso, como que uma transcendência do sentido e um fundamento ontológico da linguagem." (DELEUZE, 2004, p. 44).
} 
morreria, e não haveria mais nada. É o passado que dota a realidade de uma consistência ontológica, é ele que possibilita que haja uma continuidade entre os presentes, permitindo que afirmemos que um presente sucede a outro presente, que um presente passe, dando lugar a outro. Só podemos falar de uma repetiçáo material, porque os momentos distintos do universo são retidos por nossa consciência; do mesmo modo, apenas podemos falar da passagem dos presentes, porque esses presentes são retidos nesse imenso passado que coexiste com eles, nessa grande "Memória ontológica" que acompanha cada um de nossos estados conscientes ${ }^{10}$, retendo a totalidade destes: "[...] é o passado inteiro, integral, é todo o nosso passado que coexiste com cada presente. A célebre metáfora do cone representa esse estado completo de coexistência." (DELEUZE, 2004, p. 46). Decorre disso a seguinte afirmação de Deleuze (2004, p. 46): “[...] a duração bergsoniana define-se, finalmente, menos pela sucessão do que pela coexistência", tese esta que tem sido criticada recentemente, por alguns comentadores de Bergson. ${ }^{11}$

No entanto, essa coexistência virtual do passado com o presente também comporta uma multiplicidade de graus distintos; para Deleuze, essa diversidade de graus de intensidade da duração nos propiciará pensar outro tipo de repetição para além da repetição física da matéria, a saber, uma repetição propriamente psíquica ou espiritual, uma repetição de graus ou níveis de nosso passado (a qual desempenhará, por sua vez, uma importância fundamental, em Diferença e repetição):

A duração é certamente sucessão real, mas ela só é isso porque, mais profundamente, ela é coexistência virtual: coexistência consigo de todos os níveis, de todas as tensóes, de todos os graus de contração e distensão. Além disso, com a coexistência, é preciso reintroduzir a repetição na duração. Repetiçáo "psíquica", de um tipo totalmente distinto da repetição "física" da matéria. Repetição de "planos", em vez de ser uma repetição de elementos sobre um só e mesmo plano. Repetiçáo virtual, em vez de ser atual. Todo nosso passado se lança e se retoma de uma só vez, repe-

\footnotetext{
${ }^{10}$ Como Deleuze assevera, uma tese táo forte acerca do papel do passado e da reminiscência talvez somente tenha sido afirmada, antes na história da filosofia, por Platáo: "Uma tese como esta [acerca do passado] só tem como equivalente a tese da Reminiscência, de Platão. Também esta afirma um ser puro do passado, um ser em si do passado, uma Memória ontológica capaz de servir de fundamento ao desenrolar do tempo. Uma vez mais se faz sentir, profundamente, uma inspiração platônica em Bergson.” (DELEUZE, 2004, p. 46).

${ }^{11}$ Camille Riquier afirma que o tempo da leitura deleuzeana de Bergson "não é temporal", na medida em que ele parte não da sucessão, mas da coexistência do passado com o presente, o que iria contra a própria insistência de Bergson quanto à importância da sucessão dos momentos de consciência (RIQUIER, 2008).
} 
te-se ao mesmo tempo em todos os níveis que ele traça. (DELEUZE, 2004, p. 47).

Na concepçáo deleuzeana, a repetição material somente é possível por causa da diferença interna, mas a diferença interna somente é possível, por sua vez, em função dessa repetição espiritual, a qual produz ou recria constantemente o passado. É nesse sentido que a concepção deleuzeana do passado, em Bergsonismo, está muito longe de ser uma concepção estática, que tornaria o passado um mero repositório imutável de ideias e de lembranças. Não, de modo algum: o passado, tanto para Bergson quanto para Deleuze, está sendo constantemente reconstruido; é nessa reconstrução contínua do passado que repousa, para Bergson, o próprio "crescimento" contínuo da duração, o que é, segundo o prisma deleuzeano, a mesma coisa que afirmar o crescimento contínuo do próprio Ser. Tudo isso, pontuemos, ainda se tornará progressivamente mais claro para nós, à medida que nossa investigação avançar.

Deleuze, por fim, sintetiza o percurso brevemente percorrido por nós sob a forma de quatro paradoxos do passado:

$1^{\circ}$ colocamo-nos de súbito, de um salto, no elemento ontológico do passado (paradoxo do salto); $2^{\circ}$ há uma diferença de natureza entre o presente e o passado (paradoxo do Ser); $3^{\circ}$ o passado não se sucede ao presente que ele foi, mas coexiste com ele (paradoxo da contemporaneidade); $4^{\circ} \mathrm{o}$ que coexiste com cada presente é todo o passado, integralmente, em níveis diversos de contração e de distensão (paradoxo da repetição psíquica). (DELEUZE, 2004, p. 47).

Esses paradoxos devem ser claramente contrapostos tanto à nossa concepção ordinária do tempo quanto à maioria das teorias da memória que conhecemos, pois eles indicam que o passado tem uma natureza essencialmente ontológica, e não psicológica: o Ser, muito mais do que a totalidade do presente, significa antes a totalidade do passado, a totalidade do inconsciente, a totalidade do Virtual. Decorre disso basicamente que o passado não é algo derivado do presente, senão uma realidade tão originária quanto o próprio presente - é nesse sentido que ele é dito ser contemporâneo do próprio presente, coexistindo com este. Presente e passado são, na verdade, simplesmente dois polos da realidade, entre os quais a nossa existência consciente está constantemente transitando. 


\section{O MONISMO DA DURAÇÁO NA LEITURA DELEUZEANA DE BERGSON}

Deslindamos até aqui o primeiro deslocamento de peso operado por Deleuze em sua leitura de Bergson; ele consistiu basicamente em levar ao limite algo que se encontrava ainda em estado germinal em Bergson, a saber, essa monumental ontologização do passado. Do nosso ponto de vista, esse primeiro deslocamento não implica muita violência hermenêutica, já que os elementos para tanto se encontram claramente no texto bergsoniano, como tivemos a oportunidade de mostrar anteriormente. Com efeito, quando compreendemos o sentido pleno do "pensar em duração" bergsoniano, uma tese como esta, que advoga a precedência ontológica do passado sobre o presente, se torna perfeitamente compreensível. Náo nos parece, portanto, que resida aí a grande torção hermenêutica promovida por Deleuze em Bergson. Na verdade, ela está em outro lugar, num segundo deslocamento feito por ele na filosofia bergsoniana.

Em uma das passagens supracitadas, Deleuze expressa algo curioso, muito curioso, que tivemos de deixar momentaneamente de lado, para não atrapalhar o andamento de nossa exposição, a saber, que o passado "é eternamente, o tempo todo." (DELEUZE, 2004, p. 42, grifo nosso). ${ }^{12}$ Ora, é muito curioso que Deleuze afirme isso, já que é muito claro que, para Bergson, o passado individual de um ser humano começa a se constituir no momento em que ele desponta no mundo, ou seja, no momento de nossa geração. É bastante problemático, nesse sentido, saber se ocorre o mesmo, para Bergson, com outras espécies animais, mas é relativamente claro que esse é o caso do homem. Ora, como nenhum de nós, infelizmente, é eterno, fica difícil saber, à primeira vista, o que Deleuze tem em mente, quando alude a um passado eterno, em Bergson. Alguém poderia até contra-argumentar que, em alguns textos Bergson, aponta para a possibilidade de uma existência indefinida do ser humano no post-mortem, vide "A alma e o corpo", (BERGSON, 2009, p. 58), porém, isso não diminuiria de forma alguma o problema de saber como essa duração indefinida pode ser considerada eterna, porque ela continua envolvendo um início, uma gênese, o que contraria o próprio conceito de eternidade. ${ }^{13} \mathrm{O}$ que significa, portanto, uma duração eterna?

Começamos a vislumbrar aqui o segundo deslocamento operado por

\footnotetext{
${ }^{12}$ Em outra passagem, ele afirma novamente que o passado é um elemento ontológico "eterno e desde sempre." (DELEUZE, 2004, p. 43, grifo nosso).

${ }^{13}$ No que tange à nossa existência individual, há, segundo nosso conhecimento, apenas um texto de Bergson completamente enigmático, em que ele parece estender essa possibilidade de duração indefinida não somente ao futuro, mas ao nosso passado individual, já que ele menciona "[...] almas que, no entanto, em certo sentido, preexistiam." (BERGSON, 2005, p. 292).
} 
Deleuze. De fato, ao tratar de uma duração eterna, ele obviamente não está se referindo a nossa duração individual, psicológica, subjetiva. A que duração ele está aludindo, então? Não é à minha, nem à sua duração, mas a uma suposta duração única a permear todo o real, duração essa da qual, para Deleuze, todas as nossas durações fariam parte. Poderíamos exprimir esse ponto, enfatizando que Deleuze defende, em Bergsonismo, um radical monismo da duração, onde teríamos uma grande duração-substância, em relação à qual todas as demais duraçóes não seriam senão seus modos: aí reside, no fundo, o viés spinozano da leitura deleuzeana de Bergson. Contudo, onde Deleuze encontra em toda a obra bergsoniana elementos para defender esse monismo da duração? Não é no Ensaio (1889), evidentemente, pois Bergson ali está bem pouco interessado em grandes questóes metafísicas acerca do monismo ou pluralismo substanciais: o que lhe interessa é somente fazer uma descrição puramente imanente de nossa consciência. Poderíamos achar que os elementos desse monismo da duração estão, portanto, em Matéria e memória (1896), mas é o próprio Deleuze que afirma categoricamente o pluralismo ontológico dessa obra:

Os [textos] de Matéria e memória vão mais longe na afirmação de uma pluralidade radical das duraçôes: o universo é feito de modificaçóes, perturbaçóes, mudanças de tensão e de energia, e nada além disso. Sem dúvida, Bergson fala de uma pluralidade de ritmos de duração; mas, no contexto, a propósito de duraçóes mais ou menos lentas ou rápidas, ele precisa que cada duração é um absoluto e que cada ritmo, ele próprio, é uma duração. (DELEUZE, 2004, p. 60).

A despeito de Deleuze efetuar uma radical ontologização do passado, a partir de Matéria e memória, ele se resguarda de dizer que o Ser/Passado que ele ali enxerga possa ser pensado como uma espécie de substância única, como se vê na seguinte passagem: "Eis que, conforme Matéria e memória, a psicologia é tão somente uma abertura à ontologia, trampolim para uma 'instalação' no Ser. Mas, apenas instalados, percebemos que o Ser é múltiplo, que a duração é muito numerosa." (DELEUZE, 2004, p. 60). Ou seja, embora Deleuze afirme que, para o Bergson de Matéria e memória, o universo é uma "formidável Memória" (DELEUZE, 2004, p. 61), essa "formidável Memória" não impede a tese de uma grande pluralidade de duraçóes, tese que Deleuze caracterizará como sendo a de um "pluralismo generalizado" (2004, p. 61), o que equivale a dizer que, apesar de Deleuze ver no passado bergsoniano o próprio Ser, não devemos achar que essa tese ontológica envolva, pelo menos em Matéria e memória, uma fusão de todas as duraçôes numa única duração 
substancial indiferenciada. Até esse ponto, pensamos, a leitura de Deleuze é bastante coerente com a letra e o espírito do texto bergsoniano.

Não é, portanto, na segunda grande obra bergsoniana que Deleuze encontrará seu monismo da duração. Será, então, na próxima grande obra de Bergson, A evolução criadora (1907)? Parece que talvez seja esse o caso, dado o fato de o próprio Bergson nela abordar indiretamente o problema (BERGSON, 2005, p. 13-14); mas Deleuze ressaltará que temos ainda nessa obra um pluralismo ontológico, embora restrito, e não mais generalizado:

[Na perspectiva de $A$ evolução criadora], nenhuma coisa [material] tem uma duração própria. Teriam uma duração somente os seres semelhantes a nós (duração psicológica), depois os viventes, que formam naturalmente sistemas fechados relativos, e finalmente, o Todo do universo. Trata-se, portanto, de um pluralismo restrito, não mais generalizado. (DELEUZE, 2004, p. 61). ${ }^{14}$

Quanto a As duas fontes da moral e da religiáo (1932), por sua vez, seria muito difícil ver qualquer mudança de peso em relação a esse pluralismo ontológico, pois um dos enfoques da obra é a própria individualidade criadora dos grandes moralistas (daí decorre que Deleuze não localiza monismo algum nessa última obra). Mas se Deleuze não encontra o seu ansiado monismo da duração em nenhuma das quatro principais obras de Bergson, onde ele o encontra? Ora, esse monismo é afirmado, segundo Deleuze, justamente naquela que é a obra mais controversa de Bergson, a saber, Duração e simultaneidade (1922):

Finalmente, Duração e simultaneidade recapitula todas as hipóteses possíveis: pluralismo generalizado, pluralismo restrito, monismo. Segundo a primeira, haveria coexistência de ritmos totalmente diferentes, duraçóes realmente distintas, logo, multiplicidade radical do Tempo. [...] Daí uma segunda hipótese: fora de nós, as coisas materiais não se distinguiriam por

\footnotetext{
${ }^{14}$ Do ponto de vista da exegese, essa passagem de um pluralismo generalizado a um pluralismo restrito, em $A$ evolução criadora, já é bastante contestável, uma vez que nẫo parece que tenha havido alguma mudança substancial no pluralismo ontológico advogado pelas duas obras. Com efeito, tanto em Matéria e memória quanto em sua obra seguinte, Bergson defende claramente que a duração que ele outorga à matéria é uma duração pertencente à totalidade do universo material (que Deleuze denomina "Todo do universo"), e não aos sistemas artificialmente fechados, recortados por nossa percepção e pelas ciências. Nesse sentido, a enumeraçáo feita por Deleuze dos tipos de duração não parece variar nas duas obras, sendo muito difícil encontrar uma mudança a esse respeito entre elas (com exceção, salientemos, de que em $A$ evolução criadora Bergson também aborda uma duração divina, mas esse năo é o ponto levantado por Deleuze).
} 
duraçôes absolutamente diferentes, mas por certa maneira relativa de participar de nossa duraçáo e de escandi-la. [...] Porém, mesmo no segundo caso, perdura o mistério concernente à natureza do Todo e à nossa relação com ele. Daí a terceira hipótese: haveria uma só duração, um só tempo, do qual tudo participaria, inclusive as nossas consciências, os viventes e o todo do mundo material. Ora, para a surpresa do leitor, é essa última hipótese que Bergson apresenta como a mais satisfatória: um só Tempo, uno, universal, impessoal. Em resumo, um monismo do Tempo... (DELEUZE, 2004, p. 62).

A filosofia de Bergson envolveria então um progresso do pluralismo generalizado a um "monismo do Tempo", supostamente defendido em sua obra crítica de Einstein. Entretanto, em que lugar de Duração e simultaneidade haveria, para Deleuze, essa defesa explícita de um monismo do tempo? Para compreendê-lo, cabe relembrar brevemente o contexto da discussão operada na obra: com a teoria da relatividade restrita de Einstein (1905), surgiu a ideia de que o tempo é uma grandeza relativa, dependente do referencial inercial em que um objeto físico se encontre instalado. Entrar em detalhes sobre isso nos tomaria muito espaço e, além disso, excederia nossa competência. O que importa aqui é somente ressaltar uma consequência bem famosa dessa teoria, a qual afetava diretamente a metafísica da matéria proposta por Bergson e que, exatamente por isso, o levou a escrever essa obra polêmica. Ao que nos referimos aqui? Basicamente ao fato de que, na medida em que o tempo, na teoria da relatividade restrita, passou a ser considerado uma grandeza relativa, e náo mais absoluta, abriu-se o caminho para se pensar que o mundo material é composto por uma multiplicidade de tempos diferentes, dependendo do referencial inercial em questáo; assim, o tempo passaria mais "lentamente" para um objeto próximo da velocidade da luz do que para um objeto menos próximo dela. Disso decorreu uma série de "paradoxos", os quais, na época em que Bergson escreveu sua obra, ainda eram considerados por muitos estudiosos como "problemas" da teoria da relatividade, sendo o mais famoso destes o "paradoxo dos gêmeos". Segundo este, um gêmeo que embarcasse numa nave espacial (em Duração e simultaneidade, ainda se fala de uma bala de canhão) e viajasse numa velocidade próxima da velocidade da luz, envelheceria bem mais lentamente do que seu irmão gêmeo que permanecesse na Terra, diferença esta que poderia ser constatada com o retorno do primeiro de sua viagem ${ }^{15}$

15 As consequências desse "paradoxo", ressaltemos, têm sido experimentalmente comprovadas desde 1971, por meio de uma experiência bastante engenhosa: em vez de se usar uma nave espacial 
(exprime-se normalmente esse fato asseverando que o tempo teria então se "dilatado" para o primeiro, porque teria passado mais "lentamente" para ele). Ora, um paradoxo como esse parece ir diretamente contra a afirmação bergsoniana de que haveria uma duração única a permear o universo material, já que ela parece implicar uma variabilidade indefinida de tempos físicos. Nada de surpreendente, portanto, que Bergson tenha escrito uma obra, não para refutar o físico Albert Einstein, mas para buscar minimizar as consequências negativas da relatividade restrita no campo de sua própria discussão filosófica. Para ele, seria possível conciliar a teoria física de Einstein com sua própria metafísica, caso se concedesse que o tempo a que alude o físico é um tempo apenas "simbólico", não a própria duração real do universo. E é nesse contexto que Bergson volta a defender, em Duração e simultaneidade, a existência de uma duração única e ínfima do universo material:

Levantamos outrora uma hipótese [...] no que concerne às espécies vivas. Distinguimos durações com tensão mais ou menos alta, características dos diversos graus de consciência, que se escalonariam ao longo do reino animal. No entanto, na época não percebíamos e continuamos não vendo hoje nenhuma razão para estender para o universo material essa hipótese de uma multiplicidade de duraçóes. [...] Caso fosse preciso decidir a questão, optaríamos, no estado atual de nossos conhecimentos, pela hipótese de um Tempo material uno e universal. (BERGSON, 2006a, p. 54).

No fundo, essa afirmação de Bergson não é em nada diferente do que ele afirmava acerca da duração da matéria, em Matéria e memória, ou em $A$ evolução criadora - o mérito de uma obra como Duração e simultaneidade (e, em especial, de seu terceiro capítulo) consistiu basicamente em tornar mais clara a metafísica da matéria proposta pelo próprio Bergson. Com efeito, ao falar de “[...] um Tempo material uno e universal”, ele está simplesmente se referindo à duração única do universo material, a qual poderia operar, do seu ponto de vista, como uma espécie de tempo objetivo único para todos os sujeitos existentes, eliminando, assim, a ideia de uma diversidade de tempos sustentados pela relatividade restrita. É isso que ele tem basicamente em mente, quando afirma que "[...] uma mesma duração vai recolher ao longo do seu

ultrarrápida (cuja tecnologia não existe), sincronizam-se dois relógios atômicos, coloca-se um deles num avião voando no mesmo sentido da rotação da terra, e deixa-se o outro relógio em terra. Dada a absurda precisão do relógio atômico, qualquer variaçáo decorrente dos efeitos da relatividade é registrada, como de fato tem ocorrido desde o primeiro experimento desse tipo: o relógio que fica no avião acaba por se atrasar alguns nanossegundos em relação ao que permanece no chão. 
caminho os acontecimentos da totalidade do mundo material; [...] não haverá mais que o tempo impessoal em que todas as coisas se escoarão," (BERGSON, 2006a, p. 55).

Em nenhum momento de Duração e simultaneidade, porém, Bergson defende que esse "Tempo único" valha para além do universo material, como Deleuze busca nos convencer. Ao comentar essa passagem da obra, Deleuze surpreendentemente afirma: "Bergson conclui daí que, tanto no nível das partes atuais quanto no nível do Todo virtual, existe um Tempo e somente um." (DELEUZE, 2004, p. 65) ${ }^{16}$, ou seja, que haveria uma duração universal úni$c a$ que englobaria todas as durações individuais. Ora, embora essa afirmação possa parecer em princípio inócua, ela tem grandes consequências metafísicas, pois ela consiste em dizer que todos nós partilhamos um passado único e eterno, que estamos imersos numa monumental Memória ontológica, a qual se confunde com o próprio Ser em si. ${ }^{17}$ Nesse grande Tempo único, teríamos

${ }^{16}$ Este é um ponto muito bem ressaltado por Camille Riquier: "Deleuze se apoiava sobre Duração e simultaneidade para restaurar os direitos do monismo. Mas o tempo 'um e universal' que Bergson aí defendia não concernia senão ao 'Tempo material', no sentido em que todas as consciências humanas 'caminham no mesmo passo' sobre a rota do universo e adotam, a seu olhar, 'o mesmo ritmo de duraçấo'." (RIQUIER, 2008, p. 367, tradução nossa.)

${ }^{17}$ A fim de defender esse ponto de vista em Bergson, Deleuze lança mâo de uma passagem de Duração e simultaneidade, em que Bergson busca defender, contra Einstein, a possibilidade de podermos falar de uma noção absoluta de simultaneidade: "Quando estamos sentados na margem de um rio, o correr da água, o deslizar de um barco ou o voo de um pássaro, o murmúrio ininterrupto de nossa vida profunda são para nós três coisas diferentes ou uma só, como quisermos. Podemos interiorizar o todo, lidar com uma percepção única que carrega, confundidos, os três fluxos em seu curso; ou podemos manter exteriores os dois primeiros e repartir então a nossa atenção entre o dentro e o fora; ou, melhor ainda, podemos fazer as duas coisas concomitantemente, nossa atenção ligando e, no entanto, separando os três escoamentos, graças ao singular privilégio que ela possui de ser uma e várias. Tal é nossa primeira ideia de simultaneidade. Chamamos então simultâneos dois fluxos exteriores que ocupam a mesma duraçáo por que ambos estão compreendidos na duração de um mesmo terceiro [fluxo], o nosso: essa duração é apenas a nossa quando a nossa consciência olha somente para nós, mas torna-se igualmente a deles quando nossa atenção abarca os três fluxos num único ato indivisível.” (BERGSON, 2006a, p. 62). Compreenda-se bem: o que Bergson simplesmente defende aí é que a noção de simultaneidade tem uma origem, por assim dizer, fenomenológica, e náo física: dois fluxos ou processos podem ser considerados simultâneos entre si, quando eles são coetâneos ao nosso fluxo de pensamento. Em nenhum momento ele parece defender a hipótese metafísica de que esses três fluxos - o correr do rio, o voo do pássaro e nossa vida interior - participariam de uma mesma duraçáo cósmica, de um mesmo Tempo único, o qual abarcaria não somente esses três fluxos, mas todas as duraçóes existentes. Entretanto, é exatamente essa interpretação problemática que Deleuze vai defender, ao comentar esta passagem, citando outro texto de Bergson em seu apoio: "Se tomamos a divisão no outro sentido, vemos sempre que os fluxos, com suas diferenças de natureza, com suas diferenças de contraçâao e de distensão, comunicam-se em um só e mesmo Tempo, que é como sua condição: 'Uma mesma duração vai recolher ao longo de sua rota os acontecimentos da totalidade do mundo material; e nós poderemos eliminar as consciências humanas que havíamos inicialmente disposto de quando em quando como outras 
tấo somente um monumental inconsciente a preceder todas as consciências do mundo, o universo podendo ser pensado como um gigantesco cone invertido, como dirá em Diferença e repetição (DELEUZE, 2006, p. 129).

Devemos compreender bem o sentido desse monismo proposto por Deleuze: não se trata de afirmar que todas as consciências sejam simplesmente tragadas por essa Memória-Ser, já que ainda há, para Deleuze, a possibilidade de um pluralismo ontológico - mas no que tange estritamente ao atual, e não ao virtual. Com efeito, se seguirmos a leitura de Deleuze, veremos que, para ele, as diversas singularidades que compóem o cosmos ainda podem ser ditas diferentes entre si, havendo até mesmo a possibilidade de se falar de um "pluralismo radical”, no que tange à atualidade: “[...] no atual, reina um pluralismo irredutível tanto de mundos quanto de viventes, estando todos eles fechados sobre si mesmos" (DELEUZE, 2004, p. 84). Essa pluralidade, entretanto, somente pode ser pensada no que concerne à faceta eminentemente atual da realidade. No que diz respeito ao passado, ao inconsciente, o que encontramos é a mais profunda unidade, a despeito da multiplicidade de graus de duração que o anima: "O Ser, ou o Tempo, é uma multiplicidade; mas, precisamente, ele não é 'múltiplo', ele é Uno, conforme seu tipo de multiplicidade." (DELEUZE, 2004, p. 68). Ou seja, após aquela primeira inversão ontológica que Deleuze colheu nos textos de Bergson (privilégio ontológico do passado sobre o presente), verifica-se aqui uma segunda inversão, a qual pode ser considerada muito mais radical do que a primeira, pois indica uma completa inversão do sentido original do bergsonismo: essa inversão consistiu basicamente em despojar a consciência individual - tão importante para Bergson - de quase toda a sua consistência ontológica, tornando-a, ao fim e ao cabo, tão somente um epifenômeno desse monumental inconsciente ontológico que todas as consciências do universo compartilham. Nesse aspecto, náo devemos nos deixar enganar: embora Deleuze pareça por vezes defender um certo pluralismo em sua leitura de Bergson ${ }^{18}$, esse pluralismo sempre pressupóe um forte monismo

tantas alternâncias para o movimento do nosso pensamento; haverá táo somente o tempo impessoal, onde se escoarão todas as coisas'. Daí a triplicidade dos fluxos, sendo a nossa duração (a duração de um espectador) necessária ao mesmo tempo como fluxo e representante do Tempo em que se abismam todos os fluxos." (DELEUZE, 2004, p. 65-66).

18 "É nesse sentido que os diversos textos de Bergson se conciliam perfeitamente e não comportam contradição alguma: há tão somente um tempo (monismo), embora haja uma infinidade de fluxos atuais (pluralismo generalizado) que participam necessariamente do mesmo todo virtual (pluralismo restrito). Bergson em nada renuncia à ideia de uma diferença de natureza entre os fluxos atuais, e tampouco à ideia de diferenças de distensão ou de contração na virtualidade que englobam os fluxos e que nele se atualizam. Bergson estima que estas duas certezas não se excluem, antes implicam um 
de fundo, que é bastante estranho ao bergsonismo. Se podemos, com efeito, tomar Bergson como um autor pluralista, é porque, para ele, cada consciência, além de ser atualmente distinta de todas as outras, também conserva em si $o$ seu próprio passado, o que não é de modo algum o caso, para Deleuze.

Porém, por que Deleuze terá feito uma leitura năo apenas controversa, mas também, muito provavelmente, deliberadamente equivocada de Bergson? Não há uma resposta clara a essa questão, mas podemos talvez arriscar, a partir daquilo que se tornará mais claro somente em Diferença e repetição, que, em Bergsonismo, ele estava erguendo os pilares de sua própria filosofia, a qual náo poderia existir, tal como a conhecemos, sem essa importante inversão do bergsonismo. Com efeito, se levarmos em consideração que, ao longo de todo o seu itinerário filosófico, Deleuze buscou libertar-se dos excessos de uma tradição filosófica focada excessivamente na consciência (cuja forma cristalina é, sem dúvida, a fenomenologia husserliana), então os dois deslocamentos conceituais que acabamos de enumerar fazem todo o sentido: primeiramente, tratava-se, para Deleuze, de restituir o significado propriamente ontológico da filosofia bergsoniana, contra uma tradição de interpretaçấo excessivamente espiritualista e personalista desta (o que, do nosso ponto de vista, Deleuze conseguiu fazer com grande sucesso). Todavia, também se tratava, em segundo lugar, de transformar essa filosofia numa máquina de guerra contra toda filosofia da consciência e, no limite, contra toda tradiçáo humanista. Para isso, urgia despojar a consciência individual da importância que ela claramente ocupa no pensamento bergsoniano, reforçando seu papel absolutamente derivado em contraposição às enormes potências do inconsciente, o que ele indubitavelmente fez com essa ideia de um monismo da duraçáo, do grande Virtual do qual dependem todas as nossas pequenas consciências. Basicamente, foi assim que uma das filosofias mais personalistas conhecidas se transformou, por meio de uma grande torção hermenêutica, no mais radical anti-humanismo; mas também foi assim que Deleuze pôde erigir parte de seu próprio pensamento filosófico. Nesse sentido, podemos sustentar que, em nenhum outro lugar de Bergsonismo, Deleuze foi mais criador do que quando foi mais explicitamente infiel ao pensamento de Bergson.

MONEGALHA, Fernando. The monism of duration and the ontologization of the past: on the Deleuzian reading of Bergson. Trans/form/ação, Marília, v. 40, n. 2, p. 193-216, Abr./Jun., 2017.

tempo único. Em suma, não só as multiplicidades virtuais implicam um só tempo, como a duração, como multiplicidade virtual, é esse único e mesmo Tempo." (DELEUZE, 2004, p. 65-66). 
ABSTRACT: In this article we evaluate Deleuze's reading of Bergson, discussing two main problems: the monism of duration that Deleuze sees and defends in Bergson, and the ontologization of the past that he finds in the Bergsonian philosophy. As we shall attempt to show, if the first point (the monism of duration) seems particularly misleading, the second point (the ontologization of the past) seems to find a basis in some passages of Bergson's work.

KeYwords: Bergson. Deleuze. Monism. Duration. Ontologization.

\section{REFERÊNCIAS}

ARISTÓTELES. Metafisica. São Paulo: Loyola, 2005.

BADIOU, A. Deleuze: la clameur de l'Être. Paris: Pluriel, 2013.

BERGSON, H. Matéria e memória. São Paulo: Martins Fontes, 1999. . A evolução criadora. São Paulo: Martins Fontes, 2005. . Duração e simultaneidade. São Paulo: Martins Fontes, 2006a. . O pensamento e o movente. São Paulo: Martins Fontes, 2006b. . A energia espiritual. São Paulo: Martins Fontes, 2009.

DELEUZE, G. Bergsonismo. São Paulo: Editora 34, 2004. . Diferença e repetiçāo. Rio de Janeiro: Graal, 2006. . Conversaçōes (1972-1990). São Paulo: Editora 34, 2007.

FORNAZARI, S. O bergsonismo de Gilles Deleuze. Trans/Form/Ação, São Paulo, v. 27, n.2, p. 31-50, 2004.

HUME, D. Tratado da natureza humana. São Paulo: Editora UNESP: Imprensa Oficial do Estado, 2001.

MONEGALHA, F. O atual e o virtual em Bergson e Deleuze. 2016. 220f. Tese (Doutorado em Filosofia) - Universidade Federal de São Carlos, São Carlos, 2016.

MONTEBELLO, P. Deleuze: la passion de la pensée. Paris: Vrin, 2008.

PLATÃO. Parmênides. Rio de Janeiro: Editora PUC-Rio, 2005.

PRADO JÚNIOR, B. Presença e campo transcendental : consciência e negatividade na filosofia de Bergson. São Paulo: EDUSP, 1989.

RIQUIER, C. Bergson (d)après Deleuze. Critique: Revue Générale des Publications Françaises et Étrangères. Paris, t. LXIV, n. 732, p. 356-371, 2008.

Recebido em 18/11/2016

Aceito em 01/02/2017 